\title{
PENGEMBANGAN WEB COMPANY PROFILE TERINTEGRASI DENGAN API WHATSAPP (STUDI KASUS: AGEN SEMBAKO AL-BARKAH)
}

\author{
Abidatul Izzah ${ }^{1}$, Kunti Eliyen², Wahyu Dwi Krisnanto ${ }^{3}$, Yohan Bakhtiar ${ }^{4}$, Ellya Nurfarida ${ }^{5}$, Wiwiek \\ Kusumaning Asmoro ${ }^{6}$ \\ 1,2,3,5 Manajemen Informatika, PSDKU Polinema Kediri \\ ${ }^{4,6}$ Akuntansi, PSDKU Polinema Kediri \\ Email: ${ }^{1}$ abidatul.izzah@polinema.ac.id
}

\begin{abstract}
ABSTRAK
Pada era Marketing 5.0 seperti sekarang ini, upaya penjualan produk usaha menggunakan teknologi sangat dianjurkan. Salah satu pengusaha yang memanfaatkan teknologi informasi media sosial dalam hal ini WhtasApp adalah pemilik Agen sembako Al Barkah di daerah Kediri, Jawa Timur. Akan tetapi salah satu kendala yang ditemui adalah terbatasnya fitur story pada WhatsApp sehinggan belum bisa maksimal mengakomodir pemasaran secara lebih luas ke masyarakat. Oleh karena itu, dibutuhkan sebuah media yang dapat menampung informasi produk sembako Al-Barkah yang dapat dilihat tanpa kendala durasi waktu. Media ini diharapkan juga dapat terhubung dengan kontak WhatsApp yang telah digunakan untuk pemasaran sebelumnya. Dengan demikian, penelitian ini bertujuan untuk mengembangkan sebuah web berisi informasi usaha atau yang dikenal dengan Company Profile yang nantinya akan terintegrasi dengan media sosial WhatsApp. Tahapan pengembangan sistem dimulai dari analisis kebutuhan sistem, perancangan sistem, implementasi dalam pemrograman, dan pengujian. Hasil dari penelitian ini adalah sebuah web company profile yang telah diuji sesuai kebutuhan fungsional yang dirancang.
\end{abstract}

Kata Kunci: Company Profile, Pengembangan Perangkat Lunak, Website, WhatsApp

\section{PENDAHULUAN}

Pada era Marketing 5.0 seperti sekarang ini, penjualan produk usaha menggunakan teknologi sangat diperlukan. Teknologi dapat dimanfaatkan untuk menginformasikan profile usaha, jenis produk usaha, pemesanan, dsb. Pentingnya teknologi dalam pemasaran juga dikemukakan oleh Setiawan, EIC Marketeers, bahwa pengusaha harusnya mampu mengelola usaha yang didukung dengan implementasi NextTech (Uly 2021). Pengusaha yang dimaksud ini sejatinya meliputi usaha dalam mikro besar maupun mikro kecil. Perilaku masyarakat pada masa pandemi saat ini pun mendukung pengembangan usaha dalam pemasaran online dan media sosial. Salah satu pengusaha yang memanfaatkan adanya media sosial adalah pemilik Agen sembako Al Barkah di daerah Kediri, Jawa Timur.

Agen sembako Al Barkah merupakan usaha rintisan yang baru dijalankan mulai pertengahan tahun 2020. Proses pemasaran yang telah dilakukan terbagi menjadi du acara, yaitu online dan offline. Pemasaran online yang telah dilakukan adalah melalui aplikasi WhatsApp dengan mengiklankan produk pada fitur story. Selain story WhatsApp, pemilik juga pernah melakukan pemasaran melalui facebook, namun sekarang sudah tidak aktif lagi. Penjualan produk usaha ini juga melayani pengantaran jika memesan via WhatsApp. Pemesanan ini cukup efektif untuk menambah omzet penjualan. Akan tetapi kekurangan penjualan secara online yang ditemui saat ini adalah story WhatsApp belum bisa maksimal mengakomodir pemasaran secara lebih luas ke masyarakat. Hal ini dikarenakan terdapat 2 (dua) kelemahan utama jika menggunakan story WhatsApp sebagai alat pemasaran produk, salah satunya adalah story tersebut akan hilang dengan sendirinya selama 1 x 24 jam. Selain itu yang bisa melihat story WhatsApp adalah orang-orang tertentu saja yang menyimpan kontak nomor handphone yang bersangkutan. Di sisi lain, saat ini facebook kurang diminati oleh sebagian besar netizen di Indonesia karena sudah tergantikan dengan media sosial lain yang lebih popular. Sedangkan WhatsApp masih banyak digunakan terbukti bahwa $83 \%$ masyarakat pengguna internet di Indonesia adalah pengguna WhatsApp (Wardani 2019)

Dengan demikian, dibutuhkan sebuah media yang dapat menampung informasi produk sembako AlBarkah yang dapat dilihat tanpa kendala durasi waktu. Media ini diharapkan dapat terhubung dengan kontak WhatsApp yang telah digunakan untuk pemasaran sebelumnya. Oleh karena itu, dalam penelitian ini, akan dikembangkan sebuah web berisi informasi usaha atau yang dikenal dengan Company Profile yang nantinya akan terintegrasi dengan sosial media WhatsApp.

\section{TINJUAN PUSTAKA \\ 2.1. Penelitian Terdahulu}

Penelitian tentang pengembangan portal website untuk pemesanan dan penjualan produk telah banyak dilakukan. Sebagai contoh, telah dikembangkan sistem pemesanan dan penjualan pada Toko YT. 
Wall Interior yang menjadikan proses penyampaian informasi dari pemilik ke pelanggan menjadi lebih mudah. Hal ini karena sistem portal dapat diakses oleh masyarakat daerah tertentu namun juga dapat diakses oleh masyarakat yang berada diluar daerah. (Ismawari et al. 2020).

Penelitian yang lain tentang pengembangan sistem berbasis web yang terintegrasi dengan media komunikasi chatting untuk pemasaran produk juga telah dilakukan. Sebagai contoh, aplikasi chatbot sebagai Virtual Personal Assistant yang diintegrasikan pada website sehingga dapat memperlancar komunikasi antara PT. Tunggal Berjaya Sejahtera dengan pelanggan dalam pemasaran properti. (Mashud and Wisda 2019)

Pemanfaatan media komunikasi chatting seperti Whatsapp Gateway juga telah diterapkan pada pesan masuk aplikasi pemesanan bahan bakar minyak. Dengan adanya media ini, rekapan data permintaan bahan bakar minyak terdapat dalam aplikasi ini agar memudahkan admin dalam melaporkan permintaan bahan bakar minyak. (T. R. Wulansari, W. I. Rahayu 2019).

Di sisi lain, pemanfaatan API WhatsApp juga telah diimplementasikan di bidang Pendidikan sebagai sistem absensi online siswa. Dengan memanfaatkan API WhatsApp, setiap ketidakhadiran siswa dikirim melalui pesan WhatsApp kepada orang tua, dapat membantu guru dalam membuat kehadiran dan memfasilitasi orang tua dalam memantau kehadiran siswa di sekolah. Sistem informasi absensi yang terintegrasi dengan API WhatsApp yang dibangun memberikan kemudahan kepada guru untuk melakukan absensi siswa, membantu tata usaha sekolah dalam penyimpanan serta pengolahan data absensi siswa secara mudah dan memberikan kemudahan kepada orang tua siswa dalam memonitoring ketidakhadiran siswa di sekolah (Aprilia 2020)

Dari beberapa penelitian diatas, dapat disimpulkan bahwa penelitian tentang pengembangan sistem perangkat lunak yang berfungsi sebagai informasi sekaligus terintegrasi dengan media komunikasi WhatsApp telah dilakukan dan masih terus mengalami perkembangan.

\subsection{API WhatsApp}

WhatsApp Messenger adalah aplikasi pesan yang dapat dipasang di ponsel cerdas, namun juga dapat diakses menggunakan desktop. Lebih lanjut, WhatsApp Messenger juga merupakan aplikasi pesan lintas platform yang memungkinkan bertukar pesan tanpa pulsa karena WhatsApp Messenger menggunakan paket data internet. Saat ini WhatsApp memiliki fitur pengiriman pesan, grup, panggilan, dan pesan suara (WhatsApp n.d.). Pada tahun 2020, jumlah masyarakat Indonesia pengguna
WhatsApp mencapai jumlah 2 millyar (Pertiwi 2020). Jika diteliti lebih lanjut, maka $83 \%$ masyarakat di Indonesia adalah pengguna WhatsApp (Wardani 2019). Hal ini lah yang menyebabkan perkembangan teknologi komunikasi yang terkait dengan WhatsApp cukup populer.

Salah satu layanan WhatsApp adalah tersedianya API WhatsApp yang memungkinkan terintegrasi dengan sistem perangkat lunak lain. Dengan menggunakan API WhatsApp, sistem yang terintegrasi dapat langsung terhubung dengan aplikasi messenger dari platform mobile maupun web. Berikut ini adalah url untuk menggunakan API WhatsApp:

https://api.whatsapp.com/send?ph one $=628 \times x \times x \times x \times x \times x \&$ text $=$ Saya 20 te rtarik2 0 untuk\%20membeli 20 produ $k \circ 20$ ini $\div 20$ segera.

\section{METODOLOGI PENELITIAN}

Tahapan pengembangan sistem dimulai dari analisis kebutuhan sistem, perancangan sistem, implementasi dalam pemrograman, dan pengujian. Tahapan ini merupakan tahapan pengembangan sistem menggunakan metode Waterfall. Tahap pertama yang dilakukan yakni analisis kebutuhan yang terdiri dari analisis kebutuhan pengguna dan analisis kebutuhan perangkat. Selanjutnya, perancangan sistem meliputi penyusunan diagram usecase, diagram arsitektur sistem, dan diagram relasi entitas. Kemudian rancangan sistem diimplementasikan dengan Bahasa pemrograman PHP berbasis framework Laravel. Setelah itu, tahap terakhir adalah pengujian sistem menggunakan metode black box.

\subsection{Analisis Kebutuhan}

Analisis kebutuhan pengguna diperoleh setelah melakukan wawancara langsung dengan narasumber pemilik agen sembako Al-Barkah. Berikut ini adalah daftar kebutuhan fungsional pengguna yang akan dijadikan dasar pengembangan sistem:

\section{a. Admininstrator}

Dalam web yang akan dikembangkan, admin dapat melakukan login, melihat traffic website, dan mengelola master data seperti produk, postingan, pesan admin, informasi tentang kami, komentar produk, data pengguna, slide foto, nomor Whatsapp yang digunakan.

b. Customer

Selanjutnya, user ke dua adalah customer yakni user yang mengunjungi web portal dan dapat memesan produk. Dalam hal ini, customer diberikan akses antara lain dapat melihat produk dan 
postingan, mengirim pesan kepada admin web, dan dapat memesan produk dengan API Whatsapp.

\subsection{Perancangan Sistem}

Setelah melalui analisis kebutuhan, tahap selanjutnya adalah merancang sistem web company profile. Perancangan yang telah dilakukan digambarkan ke dalam diagram use case, diagram arsitektur sistem, dan diagram relasi entitas untuk mempermudah pengembangan. Gambar 1 menunjukkan diagram use case yang disusun. Pada rancangan tersebut, web company profile memiliki dua actor yaitu administrator dan customer. Kemudian dua actor tersebut digambarkan memiliki use case sesuai dengan analisis kebutuhan yang telah dilakukan pada subbab 3.1.

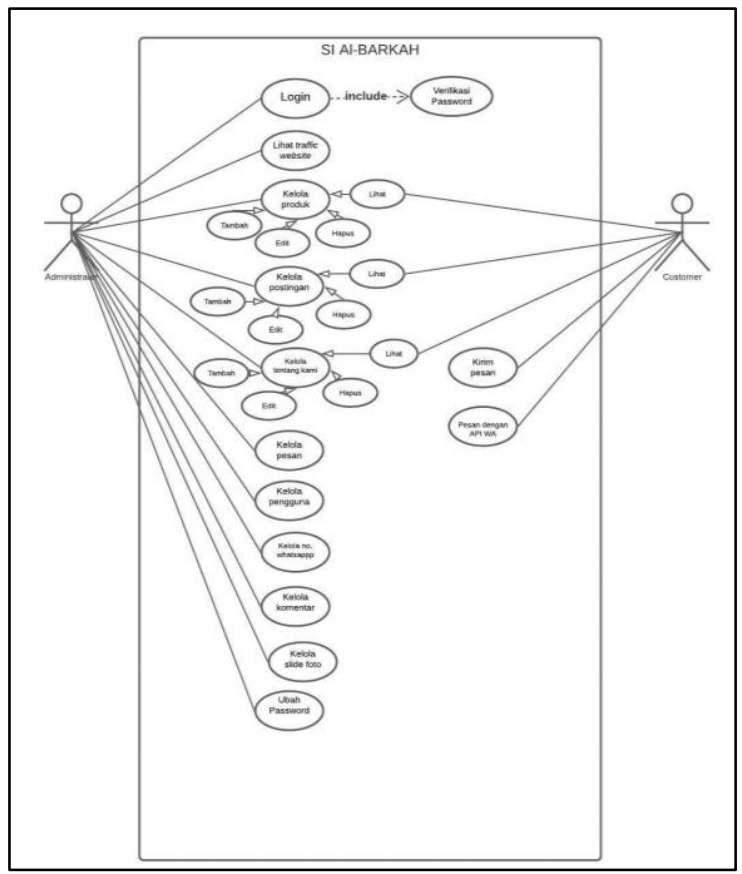

Gambar 1. Diagram Use Case

Selanjutnya adalah perancangan arsitektur sistem yang ditunjukkan pada Gambar 2. Pada gamabr tersebut, terlihat bahwa client dapat mengakses web company profile yang terintegrasi dengan API WhatsApp menggunakan perangkat desktop maupun mobile.

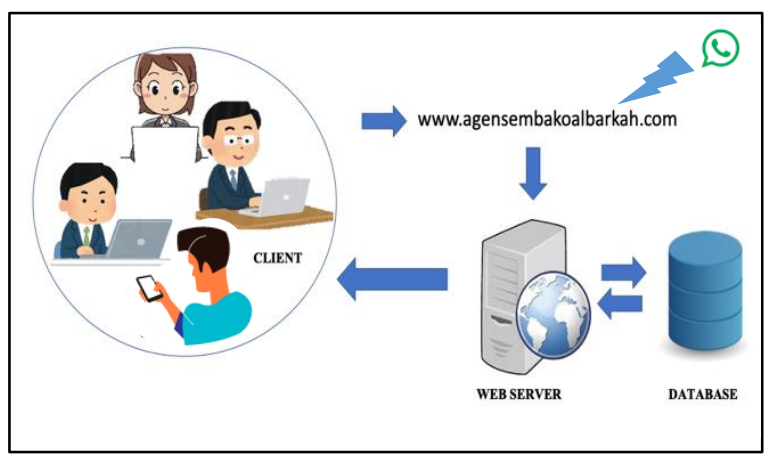

Gambar 2. Arsitektur Sistem
Perancangan sistem terakhir adalah merancang ruang penyimpanan data atau basis data. Dari analisis yang telah dilakukan, data yang perlu disimpan dalam sistem ini membutuhkan 9 entitas yakni user, produk, kategori, post, slide, nomor WhatsApp, about us, komentar, dan pesan. Dengan demikian, hubungan antar entitas tersebut digambarkan seperti pada Gambar 3.

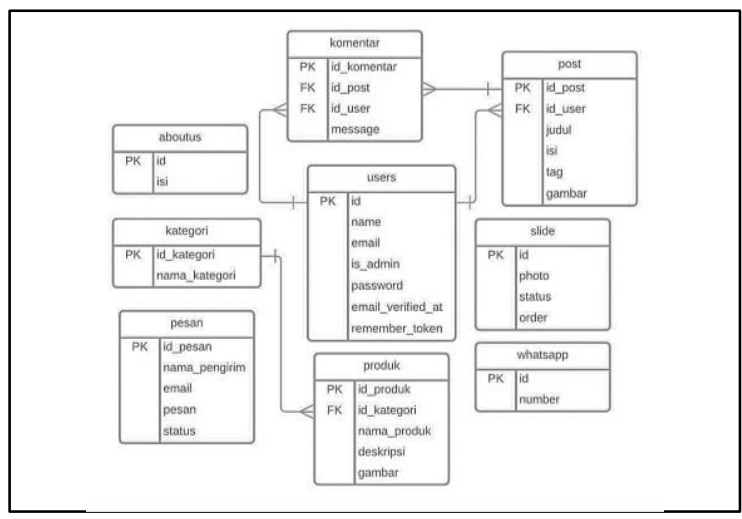

Gambar 3. Diagram relasi entitas

\section{HASIL DAN PEMBAHASAN}

\subsection{Hasil Pengembangan Sistem}

Hasil dari penelitian ini adalah sebuah web company profile yang berisi tentang produk dari Agen Sembako Al-Barkah yang terintegrasi dengan media sosial WhatsApp. Halaman utama web company profle dapat dilihat pada Gambar 4. Halaman ini memuat informasi sigkat tentang usaha Al-Barkah, daftar produk yang dijual, pengumuman, informasi lokasi usaha, dan layanan kirim pesan kepada admin.

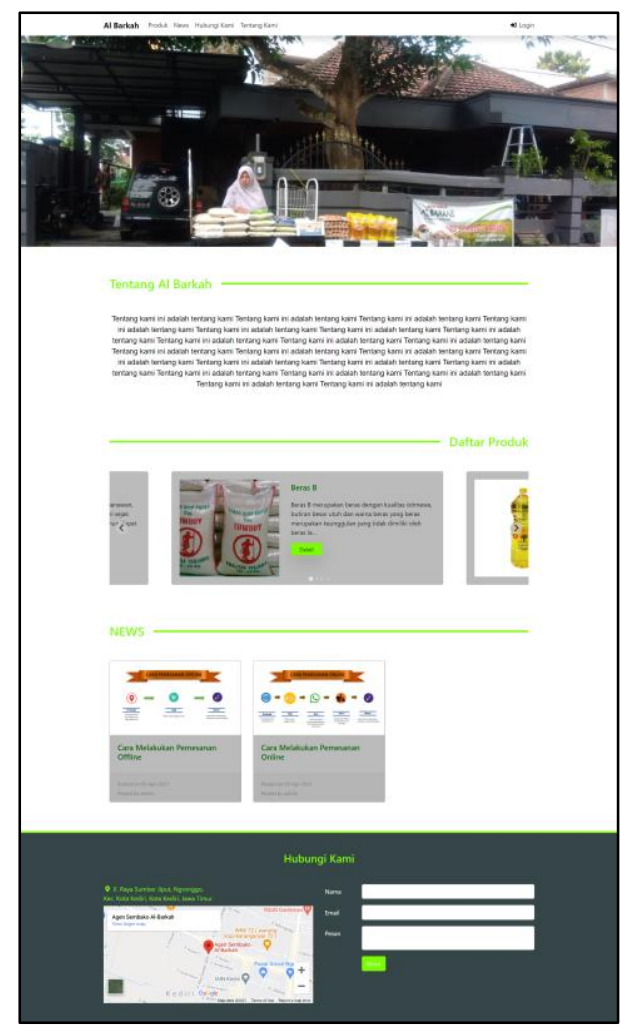

Gambar 4. Halaman Awal 
Pada daftar produk, terdapat informasi nama dan deskripsi. Untuk setiap produk terdapat button pesan yang digunakan untuk pemesanan. Button ini kemudian akan memanggil url yang menghubungkan dengan API WhatsApp. Tampilan daftar produk dapat digulir arah ke kiri dan ke kanan seperti yang ditampilkan pada Gambar 5 berikut:

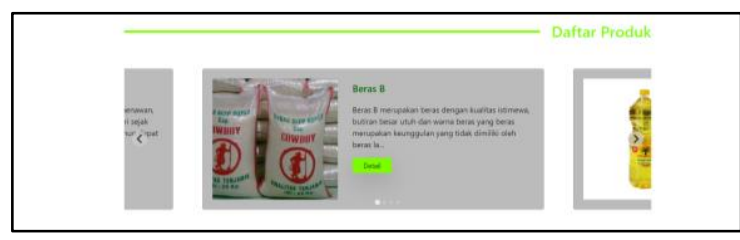

\section{Gambar 5. Halaman Produk}

Selanjutnya, jika button pesan dipilih, maka web akan langsung membuka aplikasi WhatsApp berbasis web maupun mobile tergantung dari platform yang digunakan. Pada saat memesan, secara otomatis tersedia pesan singkat seperti yang ditampilkan pada Gambar 6 berikut:

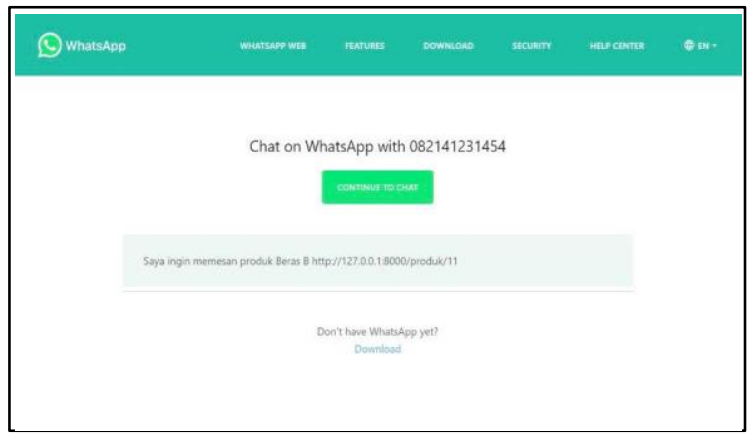

Gambar 6. Menu Pemesanan Berbasis API WhatsApp

Selanjutnya, seperti yang digambarkan di diagram arsitektur pada Gambar 2, sistem ini dapat diakses oleh dua pengguna yakni admin dan customer. Admin bertugas untuk mengelola aliran data yang masuk. Data disini meliputi data produk, data pengguna admin, data kategori, data berita/pengumuman, data pesan, dan data gambar. Pengelolaan ini mencakup proses tambah, ubah, dan hapus dari basis data. Berikut ini adalah tampilan halaman admin untuk mengelola data:

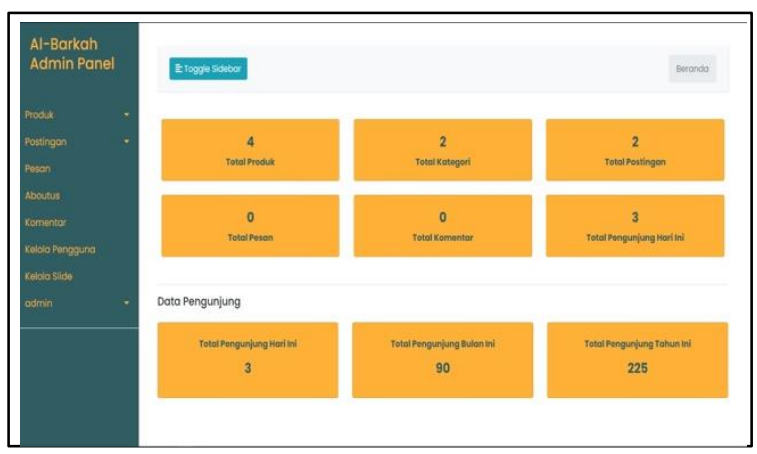

Gambar 7. Halaman Beranda Admin

\subsection{Hasil Pengujian Sistem}

Tahapan selanjutnya setelah pengembangan sistem dilakukan adalah pengujian sistem. Pengujian sistem ini dilakukan dengan menguji seluruh kebutuhan fungsional dari web yang telah dikembangkan menggunakan metode black box testing. Berikut ini adalah hasil dari pengujian company profile Agen Sembako Al-Barkah yang terintegrasi dengan API WhatsApp.

Skenario pertama pengujian adalah pengujian mengelola produk dari sisi admin. Pengujian dilakukan dengan mencoba proses tambah, ubah, dan hapus dari basis data. Tabel 1 merupakan hasil dari pengujian skenario pertama.

Tabel 1. Hasil Pengujian Mengelola Produk

\begin{tabular}{|l|l|l|}
\hline Kondisi & \multicolumn{1}{|c|}{ Indikator } & \multicolumn{1}{|c|}{ Hasil } \\
\hline Benar & Data Masukan & $\begin{array}{l}\text { Data produk berupa } \\
\text { gambar dan deskripsi }\end{array}$ \\
\cline { 2 - 3 } & $\begin{array}{l}\text { Yang } \\
\text { diharapkan }\end{array}$ & $\begin{array}{l}\text { Data produk tersimpan } \\
\text { dalam basis data }\end{array}$ \\
\cline { 2 - 3 } & Pengamatan & $\begin{array}{l}\text { Data produk tersimpan } \\
\text { dan muncul di beranda }\end{array}$ \\
\cline { 2 - 3 } Salah & Kesimpulan & Berhasil \\
\hline & Data Masukan & Salah atau kosong \\
\hline & $\begin{array}{l}\text { Yang } \\
\text { diharapkan }\end{array}$ & Muncul pesan peringatan \\
\cline { 2 - 3 } & Pengamatan & Muncul pesan peringatan \\
\hline & Kesimpulan & Berhasil \\
\hline
\end{tabular}

Skenario pengujian selanjutnya adalah pengujian mengelola pengumuman juga dari sisi admin. Pengujian dilakukan dengan mencoba proses tambah, ubah, dan hapus dari basis data. Tabel 2 merupakan hasil dari pengujian skenario kedua.

Tabel 2. Hasil Pengujian Mengelola Pengumuman/News

\begin{tabular}{|l|l|l|}
\hline Kondisi & \multicolumn{1}{|c|}{ Indikator } & \multicolumn{1}{|c|}{ Hasil } \\
\hline Benar & Data Masukan & $\begin{array}{l}\text { Data pengumuman berupa } \\
\text { gambar dan deskripsi }\end{array}$ \\
\cline { 2 - 3 } & $\begin{array}{l}\text { Yang } \\
\text { diharapkan }\end{array}$ & $\begin{array}{l}\text { Data } \\
\text { tersimpan } \\
\text { data }\end{array}$ \\
\hline
\end{tabular}




\begin{tabular}{|l|l|l|}
\hline Kondisi & \multicolumn{1}{|c|}{ Indikator } & \multicolumn{1}{|c|}{ Hasil } \\
\hline \multirow{4}{*}{ Salah } & Pengamatan & $\begin{array}{l}\text { Data pengumuman } \\
\text { tersimpan dan muncul di } \\
\text { beranda }\end{array}$ \\
\cline { 2 - 3 } & Kesimpulan & Berhasil \\
\cline { 2 - 3 } & $\begin{array}{l}\text { Yata Masukan } \\
\text { Yang } \\
\text { diharapkan }\end{array}$ & Salah atau kosong \\
\cline { 2 - 3 } & Pengamatan & Muncul pesan peringatan \\
& Kesimpulan & Berhasil \\
\hline
\end{tabular}

Skenario pengujian terakhir adalah pengujian melakukan proses pemesanan dari sisi customer. Pengujian dilakukan dengan mencoba terhubungnya web yang dibangun dengan API WhatsApp. Tabel 3 merupakan hasil dari pengujian skenario ketiga.

Tabel 3. Hasil Pengujian Proses Pemesanan

\begin{tabular}{|l|l|l|}
\hline Kondisi & \multicolumn{1}{|c|}{ Indikator } & \multicolumn{1}{|c|}{ Hasil } \\
\hline Benar & Data Masukan & $\begin{array}{l}\text { Klik tombol pesan pada } \\
\text { setiap produk }\end{array}$ \\
\cline { 2 - 3 } & $\begin{array}{l}\text { Yang } \\
\text { diharapkan }\end{array}$ & $\begin{array}{l}\text { Muncul konfirmasi untuk } \\
\text { terhubung dengan } \\
\text { WhatsApp } \\
\text { web/mobile dan mengirim } \\
\text { pesan }\end{array}$ \\
\cline { 2 - 4 } & Pengamatan & $\begin{array}{l}\text { Terhubung dengan } \\
\text { WhatsApp dan dapat } \\
\text { mengirim pesan }\end{array}$ \\
\hline Salah & Kesimpulan & Berhasil \\
\cline { 2 - 3 } & Data Masukan & $\begin{array}{l}\text { Klik tombol pesan pada } \\
\text { setiap produk dengan } \\
\text { device tidak terinstall } \\
\text { WhatsApp }\end{array}$ \\
\cline { 2 - 3 } & $\begin{array}{l}\text { Yang } \\
\text { diharapkan }\end{array}$ & Muncul pesan peringatan \\
\cline { 2 - 4 } & Pengamatan & Muncul pesan peringatan \\
\hline Kesimpulan & Berhasil \\
\hline
\end{tabular}

\section{KESIMPULAN}

Hasil dari penelitian ini adalah sebuah web Company Profile yang terintegrasi dengan media sosial WhatsApp dan telah diuji sesuai kebutuhan fungsional yang dirancang. Web ini memiliki dua pengguna yakni admin yang bertugas mengelola data dan customer yang dapat melihat informasi dan melakukan pemesanan menggunakan API WhatsApp. Web yang telah dikembangkan telah diuji menggunakan metode black box dan menunjukkan bahwa fitur dalam web ini dapat berjalan dengan baik.

Lebih lanjut, web yang dikembangkan saat ini memiliki potensi unuk pengembangan selanjutnya. Antara lain integrasi dengan sosial media lain yang cukup populer seperti Telegram, Twitter, dan Instagram.

\section{PUSTAKA}

Aprilia, Sendy. 2020. "Sistem Informasi Absensi Berbasis Website Menggunakan API WhatsApp Dengan Metodologi Incremental (Studi Kasus: SMP Negeri 29 Pekanbaru)." Journal of Applied Informatics and Computing 4(1): 38-44.

Ismawari, Afrida, Br Sitepu ${ }^{1}$, Dahri Yani, and Hakim Tanjung 2. 2020. "Rancang Bangun Aplikasi Pemesanan Dan Penjualan Berbasis Web Dan Android Pada Toko YT. Wall Interior." Jurnal FTIK 1(1): 816-28. http://ejournal.potensiutama.ac.id/ojs/index.php/FTIK/article/view/ 927.

Mashud, and Wisda. 2019. "Aplikasi Chatbot Berbasis Website Sebagai Virtual.” : 99-107.

Pertiwi, Wahyunanda Kusuma. 2020. "WhatsApp Tembus 2 Miliar Pengguna." KOMPAS.com. https://tekno.kompas.com/read/2020/02/13/18 190017/whatsapp-tembus-2-miliar-pengguna.

T. R. Wulansari, W. I. Rahayu, N. Riza. 2019. "Aplikasi Pemesanan Bahan Bakar Minyak Melalui Media Whatsapp Menggunakan Algoritma Whatsapp Gateway (Studi Kasus: Pt. Pertamina Patra Niaga).” Jurnal Teknik Informatika 11(2): 1-6.

Uly, Yohana Artha. 2021. "Pentingnya Perusahaan Gunakan Teknologi Untuk Dorong Pemasaran." KOMPAS.com. https://money.kompas.com/read/2021/02/25/1 84832926/pentingnya-perusahaan-gunakanteknologi-untuk-dorong-pemasaran.

Wardani, Agustin Setyo. 2019. "83 Persen Pengguna Internet Indonesia Pakai WhatsApp - Tekno Liputan6.Com." Liputan6.Com. https://www.liputan6.com/tekno/read/411367 8/83-persen-pengguna-internet-indonesiapakai-whatsapp.

"WhatsApp." 